See discussions, stats, and author profiles for this publication at: https://www.researchgate.net/publication/307881679

Loyaliteitsdividend, bijzondere stemrechtaandelen en de positie van minderheidsaandeelhouders

Article · July 2016

CITATIONS

0

1 author:

Bart Bootsma

Erasmus University Rotterdam

39 PUBLICATIONS 13 CITATIONS

SEE PROFILE
READS

447 


\title{
Loyaliteitsdividend, bijzondere stemrechtaandelen en de positie van minderheidsaandeelhouders
}

\author{
Midstream or IPO introduction, that's the question
}

Mr.drs. A.A. Boots $m a^{*}$

\begin{abstract}
In deze bijdrage wordt de recentelijke invoering van bijzondere stemrechtaandelen bij enkele beurs- $N V$ 's vergeleken met het indertijd bij DSM voorgestelde loyaliteitsdividend. Als belangrijk verschil wordt gesignaleerd dat het loyaliteitsdividend midstream - door een statutenwijziging bij een bestaande beurs-NV met zittende publieke aandeelhouders werd voorgesteld, terwijl de bijzondere stemrechtaandelen voorafgaand aan een beursgang (IPO) of in het kader van een grensoverschrijdende statutaire zetelverplaatsing bij een nieuwe (holding)vennootschap zijn ingevoerd. Beargumenteerd wordt dat dit verschil doorwerkt in de positie van minderheidsaandeelhouders; met name bij midstream-invoering zouden minderheidsaandeelhouders bekneld kunnen raken. Tegen deze achtergrond wordt in de bijdrage ingegaan op de voorstellen van Eumedion voor regulering van bijzondere stemrechtaandelen.
\end{abstract}

\section{Inleiding}

'In het kader van corporate governance is er een brede discussie gaande met betrekking tot het langetermijncommitment van aandeelhouders. Gezien onze focus op waardecreatie voor de lange termijn overwegen we de invoering van een nieuw dividendinitiatief, het zogen[oe]mde loyaliteitsdividend, dat ons de mogelijkheid geeft om rechtstreeks te communiceren met onze aandeelhouders en waarmee we langetermijnaandeelhouders belonen.'

Het is alweer bijna tien jaar geleden dat Koninklijke DSM NV (hierna: DSM) met deze woorden haar plannen voor invoering van een loyaliteitsdividend wereldkundig makte. Zoals bekend is de poging daartoe in 2007 gestrand, na een door een groep Amerikaanse minderheidsaandeelhouders geëntameerde

Mr. drs. A.A. Bootsma is werkzaam als promovendus bij Erasmus School of Law en verbonden aan het Instituut voor Ondernemingsrecht (IvO) en het IvO Center for Financial Law \& Governance (ICFG).

1. Persbericht DSM van 27 september 2006, kenbaar uit overweging 1.9 van de conclusie van A-G Timmerman voor HR 14 december 2007, JOR 2008/11 m.nt. Doorman, NJ 2008/105 m.nt. Maeijer (DSM). enquêteprocedure. ${ }^{2}$ De cassatie in het belang der wet kon daar geen verandering meer in brengen. ${ }^{3}$

De tijd heeft intussen niet stilgestaan. Zowel de Monitoring Commissie Corporate Governance Code (hierna: Monitoring Commissie $)^{4}$ als de Nederlandse wetgever ${ }^{5}$ als de EU-wetge$\operatorname{ver}^{6}$ hebben het onderwerp in het vizier, maar tot regulering van loyaliteitsaandelen is het vooralsnog niet gekomen. ${ }^{7}$

Dat een uitdrukkelijke wettelijke basis voor loyaliteitsaandelen ontbreekt, heeft een aantal Nederlandse beursvennootschappen niet van invoering weerhouden. $\mathrm{CNH}$ Industrial NV (hierna: CNH) (2013), Fiat Chrysler Automobiles NV (hierna: FCA) (2014) en Ferrari NV (2015) hebben een loyaliteitsstemrecht ingevoerd. ${ }^{8}$ Naast het loyaliteitsstemrecht

2. Hof Amsterdam (OK) 28 maart 2007, JOR 2007/118 m.nt. Brink (DSM).

3. HR 14 december 2007, JOR 2008/11 m.nt. Doorman, NJ 2008/105 m.nt. Maeijer (DSM).

4. Zie bijv. Monitoring Commissie Corporate Governance Code, Advies over de verhouding tussen vennootschap en aandeelhouders en over het toepassingsbereik van de Code, mei 2007, p. 14-15, waarover C.W. de Monchy in Ondernemingsrecht 2007/120 en - meer recentelijk Monitoring Commissie Corporate Governance Code, Rapport monitoring boekjaar 2014, februari 2016, p. 49-50, waarover A.A. Bootsma in Ondernemingsrecht 2016/36.

5. Zie bijv. de contouren van een wettelijke regeling in Kamerstukken II 2010/11, 31980, 48, waarover E. Stegerhoek in Ondernemingsrecht $2011 / 67$.

6. In het kader van de voorstellen voor aanpassing van de Richtlijn aandeelhoudersrechten (2007/36/EG), waarover M. van Olffen, Kapitaalverschaffers en de Aandeelhoudersrichtlijn, in: G. van Solinge e.a., Nederland, het Delaware van Europa? (Serie vanwege het Van der Heijden Instituut, deel 135), Deventer: Wolters Kluwer 2016 (te verschijnen) en A.A. Bootsma in Ondernemingsrecht 2015/19.

7. Zie A.A. Bootsma, Nederland, het Delaware van Europa? Verslag van het Van der Heijden Congres 2015, Ondernemingsrecht 2016 (te verschijnen).

8. Zie hierover M. van Olffen, Nederlandse loyaliteitsaandelen met een Frans sausje, Ondernemingsrecht 2013/67 en A.A. Bootsma, Loyaliteitsstemrecht naar Italiaans recht en bij Fiat Chrysler Automobiles NV, Ondernemingsrecht 2015/5. 


\section{Maandblad}

Ondernemingsrecht

bij de 'Fiat-drieling'? kent Cnova NV (2015) een regeling van meervoudig - dubbel - stemrecht voor de oprichter ${ }^{10}$ en bestaat bij Yandex NV (2011) en Altice NV (2015) een dualclass-aandelenstructuur met een klasse low voting aandelen en een klasse high voting aandelen met een stemverhouding van respectievelijk 1:10 en 1:25. ${ }^{11}$ Deze ontwikkeling houdt verband met de toenemende concentratie van de aandeelhoudersstructuur bij Nederlandse beursvennootschappen. ${ }^{12}$ Door 'bijzondere stemrechtaandelen' ${ }^{\prime 3}$ weten grootaandeelhouders hun zeggenschap bij de genoemde vennootschappen te versterken. Eumedion is bevreesd voor de positie van minderheidsaandeelhouders bij beursvennootschappen met een controlerende aandeelhouder en heeft op 15 oktober 2015 in een concept-position paper een aantal voorstellen gedaan om tot een betere borging van de positie van minderheidsaandeelhouders te komen. ${ }^{14}$ Op 28 juni 2016 is de position paper, na een consultatieproces waarin belangstellenden op de conceptvoorstellen konden reageren, definitief vastgesteld. ${ }^{15}$

Een vraag die mij in dit verband intrigeert, en waar ik in het bestek van deze bijdrage een antwoord op probeer te formuleren, is waarom vooralsnog bij geen van de genoemde beursvennootschappen door minderheidsaandeelhouders is verzocht om een enquêteprocedure, zoals indertijd bij het loyaliteitsdi-

9. Zie C.J.C. de Brauw, NV's met een beursnotering buiten Nederland; een internationaal perspectief op het Nederlandse model, in: G. van Solinge e.a., Nederland, het Delaware van Europa? (Serie vanwege het Van der Heijden Instituut, deel 135), Deventer: Wolters Kluwer 2016 (te verschijnen).

10. Abma schaart de stemrechtregeling van Cnova NV onder loyaliteitsstemrecht. Zie R. Abma, Kroniek van het seizoen van jaarlijkse algemene vergaderingen 2015, Ondernemingsrecht 2015/105. Het meervoudig (dubbel) stemrecht bij Cnova verschilt in zoverre van loyaliteitsstemrecht dat het uitsluitend aan de controlerende aandeelhouder wordt toegekend en de toekenning niet afhankelijk is gesteld van een houdtermijn van de aandelen. Zie ook A.A. Bootsma, J.B.S. Hijink \& L. in 't Veld, Multiple corporate citizenship, Ondernemingsrecht 2015/120.

11. Zie over dual-class-aandelen in meer detail H.M. Parson, High/low voting stock bij beursvennootschappen, V\&O 2000, afl. 2, p. 29-32, M. van Olffen, Beschermingsmaatregelen in de 21e eeuw (oratie Nijmegen), Deventer: Kluwer 2000 en - meer recentelijk - M.P. Buirma, High/low voting stock. Een nieuwe trend?, TOP 2016, afl. 1. Zie nader over de genoemde vennootschappen R. Abma, De uitwassen van ons flexibele vennootschapsrecht, Ondernemingsrecht 2015/87 en Bootsma, Hijink \& In't Veld 2015.

12. Zie voor gegevens over de concentratie van de aandeelhoudersstructuur bij beurs-NV's Abma 2015 (kroniek) en A.A. Bootsma \& J.B.S. Hijink, De beurs-NV in den vreemde, Een perspectief op modernisering van het NV-recht, Ondernemingsrecht 2014/15. Zie ook Eumedion, Position paper. Positie minderheidsaandeelhouders in ondernemingen met controlerend aandeelhouder, 15 oktober 2015, p. 3-4 (en 28 juni 2016, p. 3-4), beschikbaar via <www.eumedion.nl>.

13. De Fiat-drieling omschrijft het loyaliteitsstemrecht als bijzondere stemrechtaandelen (special voting shares). Ik gebruik de term bijzondere stemrechtaandelen in deze bijdrage in ruimere zin, inclusief dual-classaandelenstructuren en andere vormen van meervoudig stemrecht.

14. Eumedion 2015.

15. Zie Eumedion, Position paper. Positie minderheidsaandeelhouders in ondernemingen met controlerend aandeelhouder, 28 juni 2016, beschikbaar via <www.eumedion.nl>. De position paper gaat vergezeld van een feedback statement over de consultatie van de concept-position paper, eveneens beschikbaar via <www.eumedion.nl >. Zie over de definitieve versie van de position paper het naschrift bij deze bijdrage. vidend van DSM is gebeurd. In de Eumedion-position paper wordt het enquêterecht - terecht - als een belangrijke bestaande waarborg voor de bescherming van de belangen van minderheidsaandeelhouders genoemd. ${ }^{16}$ Door minderheidsaandeelhouders zouden verschillende juridische gronden kunnen worden ingebracht tegen de invoering van bijzondere stemrechtaandelen. ${ }^{17}$

Anders gesteld, waarin verschillen de casus van CNH, FCA, Ferrari, Cnova, Yandex en Altice van DSM? Ten minste vijf verschillen kunnen worden genoemd (par. 2 en 3). Vervolgens ga ik in op de discussie over een wettelijke regeling voor bijzondere stemrechtaandelen in het licht van de Eumedion-position paper (par. 4). Ik rond af met een conclusie (par. 5).

\section{Verschillen tussen loyaliteitsdividend bij DSM en bijzondere stemrechtaandelen bij enkele beurs-NV's}

\subsection{Dividend of stemrecht}

Een eerste - voor de hand liggend - verschil is dat het bij DSM om een loyaliteitsdividend ging en bij de overige genoemde vennootschappen om vormen van meervoudig stemrecht. Verondersteld zou kunnen worden dat aandeelhouders eerder geneigd zijn actie te ondernemen als hun financiële rechten direct dreigen te worden aangetast. ${ }^{18}$ Voor DSM-aandeelhouders die niet aan de minimale houdtermijn van drie jaar zouden voldoen, zou de invoering van het loyaliteitsdividend resulteren in een lager dividend. ${ }^{19} \mathrm{Bij}$ een wijziging in de zeggenschapsrechten wordt de financiële positie van aandeelhouders niet rechtstreeks geraakt. Dat de zeggenschap over de vennootschap en de daarmee verbonden onderneming in handen

16. Zie Eumedion 2015, p. 6 (en Eumedion 2016, p. 7). Zie anders over de toepassing van het enquêterecht bij beurs-NV's: G.T.M.J. Raaijmakers \& M.J.G.C. Raaijmakers, De NV in 2020, Ondernemingsrecht 2014/12 en M.J.G.C. Raaijmakers \& G.J.H. van der Sangen, Enquêterecht en beursvennootschappen: een anomalie?, TvOB 2014, afl. 3, p. 84-92.

17. Zie in algemene zin P. Cronheim, die in The Wall Street Journal van 6 augustus 2015 ('Patrick Drahi cements control of Altice in move to the Netherlands') laat optekenen dat: 'in general, some of these newcomers are very creative, and introduce innovative governance structures. It remains to be seen if they will stand up in court if challenged.' Zie specifiek over de invoering van loyaliteitsstemrecht bij FCA Bootsma 2015.

18. Vgl. bijv. A. de Jong, G.M.H. Mertens \& P.G.J. Roosenboom, Shareholders' voting at general meetings: Evidence from the Netherlands, Journal of Management \& Governance (10) 2006, p. 353-380 en P. Linge \& E. Theissen, Determinanten der Aktionärspräsenz auf Hauptversammlungen deutscher Aktiengesellschaften, CFR-Working Paper No. 08-05.

19. Het DSM-plan werkte zero-sum; het aanvullende dividend voor langetermijnaandeelhouders correspondeerde met een lager dividend voor de overige aandeelhouders. 
is van een controlerende aandeelhouder is voor een minderheidsaandeelhouder niet per definitie nadelig. ${ }^{20}$

\subsection{Precedentwerking DSM-beschikking}

Een tweede verschil is dat DSM als voorloper een voorbeeld heeft gesteld voor de andere beursvennootschappen. Gesteld zou kunnen worden dat met de DSM-beschikking ${ }^{21}$ tevens de weg vrijgemaakt is voor invoering van bijzondere stemrechtaandelen. De Hoge Raad heeft echter in de DSM-beschikking, kort gezegd, slechts geoordeeld dat invoering van loyaliteitsdividend binnen de grenzen van artikel 2:92 lid 2 van het Burgerlijk Wetboek (BW) is toegestaan, waardoor bij het ontbreken van een wettelijke regeling over loyaliteitsstemrecht nog juridische onzekerheid is blijven bestaan. ${ }^{22} \mathrm{Bij}$ dual-classaandelenstructuren lijkt de juridische onzekerheid overigens minder groot vanwege enkele precedenten, waarvan KPNQwest NV de bekendste was. ${ }^{23}$ In dit verband mag ook niet onvermeld blijven dat de Hoge Raad in de DSM-beschikking de Ondernemingskamer aanspoort tot een terughoudend gebruik van het treffen van onmiddellijke voorzieningen in de zin van artikel 2:349a lid $2 \mathrm{BW}$, zolang nog geen onderzoek is gelast. ${ }^{24}$ De Ondernemingskamer (of anders de voorzieningenrechter ${ }^{25}$ ) zou na de DSM-beschikking in beginsel nog

20. Zie in theoretische zin: Z. Goshen \& A. Hamdani, Corporate control and idiosyncratic vision, Yale Law Journal (125) 2016, p. 560: 'Our framework identifies a fundamental tradeoff, stemming from asymmetric information and differences of opinion, between the entrepreneur's pursuit of her idiosyncratic vision and investor's need for protection against agency costs. Entrepreneurs and investors address this inevitable conflict through different ownership structures, each with different allocations of control and cash-flow rights. Concentrated ownership, therefore, should not be viewed as an unalloyed evil. To the contrary, it creates value for controlling and minority shareholders alike.' Zie voor een empirische onderbouwing K.J.M. Cremers, S. Masconale \& S.M. Sepe, Commitment and entrenchment in corporate governance, Northwestern University Law Review (110) 2016, p. 727-810 en K.J.M. Cremers \& S.M. Sepe, The shareholder value of empowered boards, Stanford Law Review (68) 2016, p. 67-148. Vgl. de opvatting van de minister van Veiligheid en Justitie in Kamerstukken II 2015/16, Aanhangsel, 667, p. 2: ' $[\mathrm{I}] \mathrm{k}[\mathrm{acht}]$ het voorstelbaar dat vennootschappen, wellicht meer dan voorheen, op zoek zijn naar stabiele aandeelhouders die zich voor langere tijd aan de vennootschap verbinden. Een controlerend aandeelhouder is doorgaans voor de langere termijn betrokken bij de vennootschap, maar er kunnen ook risico's kleven aan concentratie van zeggenschap bij een grootaandeelhouder.'

21. HR 14 december 2007, JOR 2008/11 m.nt. Doorman, NJ 2008/105 m.nt. Maeijer (DSM).

22. Zie bijv. Asser/Van Solinge \& Nieuwe Weme 2-IIa 2013/315, waarin nog wordt verdedigd dat ' $[t]$ oekenning van extra stemrecht een wettelijke basis [vergt] die thans ontbreekt voor de NV'. Anders reeds: J.M. de Jongh, Het loyaliteitsstemrecht, Ondernemingsrecht 2009/105. Zie ook Kamerstukken II 2010/11,31980, 48, p. 1: 'Het huidige recht laat reeds toe dat een $[\mathrm{NV}]$ de aandeelhouders die gedurende langere tijd in de onderneming hebben geïnvesteerd, beloont met een extra stemrecht of dividend zolang hun aandeelhouderschap voortduurt. (...) In de praktijk is echter wel opgemerkt dat de huidige wetgeving teveel beperkingen inhoudt en dat onzekerheid bestaat over de voorwaarden waaronder van de mogelijkheden gebruik kan worden gemaakt.'

23. Van Olffen 2000, p. 4 noemt daarnaast Benckiser NV, als eerste voorbeeld van een beurs-NV met een dual-class-aandelenstructuur. De Brauw 2016 wijst voorts op Ispat International NV als voorbeeld uit het verleden van een beurs-NV met een dual-class-aandelenstructuur. steeds bij het toetsen van bijzondere stemrechtaandelen kunnen worden ingeschakeld. ${ }^{26}$

\subsection{Aandeelhoudersstructuur}

In de derde plaats is van belang dat DSM een relatief verspreid aandelenbezit kende, ${ }^{27}$ terwijl bij de andere vennootschappen zonder uitzondering controlerende aandeelhouders aanwezig zijn. ${ }^{28}$ Het verschil in aandeelhoudersstructuur is relevant, omdat mogelijke bevoordeling van de controlerende aandeelhouder in een dergelijke situatie juist éérder dan bij een meer verspreid aandelenbezit (zoals in de DSM-casus) aanleiding zou kunnen geven tot het starten van een juridische procedure door minderheidsaandeelhouders.

\subsection{Locatie beursnotering}

Een vierde verschil is gelegen in de locatie waar de aandelen in de vennootschappen worden verhandeld. De aandelen in DSM zijn toegelaten tot de handel op Euronext Amsterdam, terwijl de aandelen in CNH, FCA, Ferrari, Cnova en Yandex te New York - op de NYSE of NASDAQ - worden verhandeld. Dat de aandelen in deze vennootschappen buiten Nederland zijn toegelaten tot de beurshandel geeft een belangrijke nuancering op de door Abma geuite vrees voor een aantasting van het Nederlandse beleggingsklimaat. ${ }^{29}$ In de Verenigde Staten (VS) vallen deze vennootschappen met bijzondere stem-

24. Zie o.a. A.J.P. Schild, Het loyaliteitsdividend van DSM en de onmiddellijke voorzieningen van de ondernemingskamer, MvV 2008, afl. 2, p. 30-37 en M.W. Josephus Jitta in zijn noot onder HR 14 december 2007 (DSM) in Ondernemingsrecht 2008/11. Zie ook de codificatie in art. 2:349a BW bij Wet van 18 juni 2012 (Stb. 2012, 274), die per 1 januari 2013 in werking is getreden.

25. Vgl. bijv. Rb. Den Haag 17 maart 2015, JOR 2015/135 m.nt. Nowak, Ondernemingsrecht 2015/160 m.nt. R.A.F. Timmermans (Boskalis) Fugro), onlangs in hoger beroep bevestigd. Zie Hof Den Haag 31 mei 2016, ECLI:NL:GHDHA:2016:1531.

26. Vgl. ook C.D.J. Bulten \& C.J.H. Jansen, Rechterlijk activisme: waar liggen de grenzen van rechtsvorming door de Ondernemingskamer?, Ondernemingsrecht 2015/20.

27. De vijf aandeelhouders met een substantiële deelneming in het aandelenkapitaal van DSM - ABN AMRO Holding NV, Aviva Plc, Capital Research and Management Company, Coöperatieve Centrale Raiffeissen-Boerenleenbank BA en ING Groep NV - vertegenwoordigden per 1 januari 2007 gezamenlijk ongeveer 30\% van de stemrechten in DSM, bij een stemmenopkomst op de algemene vergadering van ongeveer $47 \%$. Gegevens ontleend aan het DSM Jaarverslag 2006, het AFM-register substantiële deelnemingen en brutoshortposities en de website van DSM. Voor een deel gaat het hier overigens om cumulatief preferente aandelen, waarmee reeds werd afgeweken van het proportionaliteitsbeginsel (one share, one vote). Zie daarover ook het FD van 19 april 2016 ('Aandeelhouders DSM in opstand om onevenredig stemrecht'). Het beeld van een relatief, bij institutionele partijen geconcentreerd aandeelhouderschap strookt met A. de Jong, G.M.H. Mertens \& P.G.J. Roosenboom, Hoe actief zijn aandeelhouders in Nederland? Een empirische analyse van opkomst en stemgedrag, MAB 2005, afl. 3, p. 106.

28. In lijn met Eumedion 2015; 2016 gedefinieerd als partijen die meer dan $30 \%$ van de stemrechten houden.

29. Zie over dit punt ook Bootsma, Hijink \& In 't Veld 2015. 


\section{Maandblad \\ Ondernemingsrecht}

rechtaandelen niet, althans minder, ${ }^{30}$ uit de toon dan in Nederland, hetgeen eveneens een deel van de verklaring zou kunnen vormen waarom minderheidsaandeelhouders bij deze vennootschappen geen juridische actie hebben ondernomen tegen de bijzondere stemrechtaandelen. ${ }^{31}$ Dit verschil biedt echter evenmin een volledig sluitende verklaring. Bovendien ontbreekt Altice in de opsomming van vennootschappen. De aandelen in Altice worden, evenals die in DSM, verhandeld op Euronext Amsterdam.

\subsection{Moment van invoering}

Het vijfde verschil dat ik signaleer, is dat DSM de loyaliteitsaandelen 'tussentijds' (midstream) - daarmee bedoel ik: door middel van een statutenwijziging bij een bestaande beurs-NV met zittende aandeelhouders - wilde invoeren. In de andere casus is zonder uitzondering sprake van invoering bij een 'nieuwe' beurs-NV, voorafgaand aan een beursgang (IPO) of in het kader van een grensoverschrijdende statutaire zetelverplaatsing naar Nederland, waarbij eveneens een nieuwe Nederlandse holdingvennootschap wordt opgericht. Waarom dit onderscheid tussen initiële en tussentijdse invoering relevant is voor de positie van minderheidsaandeelhouders, kan worden verduidelijkt aan de hand van een korte rechtsvergelijking met de VS, waarbij zowel het statenrecht - de Amerikaanse staat Delaware is leidend op het terrein van vennootschapsrecht ${ }^{32}-$ als het federale effectenrecht en de noteringsvoorwaarden van NYSE en NASDAQ relevant zijn.

\section{Midstream-versus IPO-invoering naar Amerikaans en Nederlands recht}

\subsection{Verenigde Staten}

Het vennootschapsrecht van de Amerikaanse staat Delaware biedt flexibiliteit bij de invoering van bijzondere stemrechtaandelen. Illustratief is een casus waarin de midstream-invoering van een loyaliteitsstemrecht bij een beursvennootschap centraal stond, waarvan de facto vooral de controlerende aan-

30. Bij Amerikaanse beursvennootschappen met reeds een dual-class-aandelenstructuur, zoals Google (Alphabet) en Facebook, ligt recentelijk de midstream-invoering (zie nader par. 2.5) van een derde klasse stemrechtloze aandelen (class C non-voting shares) onder vuur, zie bijv. P. Lee, Protecting public shareholders: The case of Google's recapitalization, Harvard Business Law Review (5) 2015, afl. 2, p. 281-299.

31. Door een aantal Amerikaanse beursvennootschappen wordt met name gebruik gemaakt van dual-class-aandelen (zie noot 30), maar de belangstelling in de literatuur voor loyaliteitsstemrecht (zogenoemd timephased voting of tenure voting) - als minder vergaande afwijking van het proportionaliteitsbeginsel (one share, one vote) dan bij dual-class-aandelen - neemt toe. Zie bijv. L.L. Dallas \& J.M. Barry, Long-term shareholders and time-phased voting, Delaware Journal of Corporate Law (40) 2015, p. 541-646 en D.J. Berger, S.M. Davidoff \& A.J. Benjamin, Tenure voting and the U.S. public company (Working paper), maart 2016, beschikbaar via <www.ssrn.com > . Zie recentelijk ook P. Clapman $\&$ R. Koppes, Time to rethink 'one share, one vote'?, The Wall Street Journal 23 juni 2016.

32. Zie <www.corp.delaware.gov/aboutagency.shtml> (geraadpleegd op 26 juni 2016), waar gerapporteerd wordt dat: '[m]ore than $50 \%$ of all publicly-traded companies in the United States including $64 \%$ of the Fortune 500 have chosen Delaware as their legal home'. deelhouder zou profiteren. In een 3-2 split decision ${ }^{33}$ komt het Delaware Supreme Court tot het oordeel dat de invoering van loyaliteitsstemrecht bij de desbetreffende vennootschap geoorloofd is. Het Delaware Supreme Court oordeelde in hoogste instantie dat de invoering terughoudend - dat wil zeggen: met toepassing van de business judgment rule - getoetst dient te worden. ${ }^{34} \mathrm{Niet}$ is vereist dat een meerderheid van de minderheidsaandeelhouders - majority of minority - met de invoering instemt.

De Amerikaanse beurstoezichthouder SEC heeft getracht de invoering van bijzondere stemrechtaandelen (time-phased voting, dual-class-aandelen en andere vormen van meervoudig stemrecht) aan banden te leggen in het federale effectenrecht. ${ }^{35}$ Nadat die poging vanwege het overschrijden van de regelgevende bevoegdheden door de SEC in een procedure bij het Supreme Court (D.C. Circuit) ${ }^{36}$ strandde, heeft de SEC de Amerikaanse effectenbeurzen ertoe kunnen bewegen in de noteringsvoorwaarden op te nemen dat midstream-invoering van bijzondere stemrechtaandelen in beginsel niet is toegestaan. ${ }^{37}$ Voorafgaand aan een IPO kunnen deze stemrechtregelingen nog steeds worden ingevoerd, van welke mogelijkheid de laatste jaren veelvuldig gebruik is gemaakt. ${ }^{38}$

\subsection{Nederland}

Hoe laat dit onderscheid tussen midstream-en IPO-invoering zich vertalen naar de Nederlandse context? In het Nederlandse vennootschapsrecht wordt niet expliciet een dergelijk

33. Waarbij twee van de vijf Justices in het Delaware Supreme Court een dissenting opinion hadden. Dergelijke 3-2 split decisions komen betrekkelijk weinig voor. Zie in die zin B.F. Assink, Rechterlijke toetsing van bestuurlijk gedrag. Binnen het vennootschapsrecht van Nederland en Delaware (diss. Rotterdam; Uitgave vanwege het Instituut voor Ondernemingsrecht, deel 59), Deventer: Kluwer 2007, p. 76.

34. Williams v. Geier, 671 A.2d 1368 (Del. 1996). Deze uitspraak komt niet aan de orde in de conclusie van A-G Timmerman voor HR 14 december 2007, JOR 2008/11 m.nt. Doorman, NJ 2008/105 m.nt. Maeijer (DSM), waar de rechtsvergelijking zich richt op Frankrijk, Spanje en Duitsland (overweging 3.14-3.21). Zie over Williams v. Geier vanuit het gezichtspunt van rechterlijke toetsing Assink 2007, o.a. op p. 343-344 en M.J. van Ginneken, Vijandige overnames, de rol van de vennootschapsleiding in Nederland en de Verenigde Staten (diss. Amsterdam UvA; Uitgave vanwege het Instituut voor Ondernemingsrecht, deel 79), Deventer: Kluwer 2010, p. 138 en 150.

35. Zie over deze zogenoemde Rule 19c-4 bijv. S.M. Bainbridge, The short life and resurrection of SEC Rule 19c-4, Washington University Law Quarterly (69) 1991, p. 565-634. Zie ook Dallas \& Barry 2015 en Berger, Davidoff \& Benjamin 2016.

36. Business Roundtable v. SEC, 905 F.2d 406 (D.C. 1990).

37. Zie voor de relevante passages uit noteringsvoorwaarden van de NYSE en NASDAQ bijlage 2 bij Eumedion 2015. Berger, Davidoff \& Benjamin 2016, p. 38 beargumenteren echter: 'By demonstrating a unique need to manage for the long term and highlighting concerns over market short-termism, many companies could have a strong argument for "flexible" treatment by the exchanges that would permit tenure voting.'

38. Zie voor empirische gegevens S.M. Davidoff, Shareholders vote with their dollars to have less of a say, The New York Times 4 november 2015 , te raadplegen via <www.nytimes.com>. 
onderscheid gemaakt. ${ }^{39}$ Midstream-invoering van bijvoorbeeld loyaliteitsaandelen is naar Nederlands recht in beginsel mogelijk. ${ }^{40}$ Uit de DSM-beschikking kan worden afgeleid dat daarbij de gewone regels voor een statutenwijziging gelden. ${ }^{41}$ Een besluit tot statutenwijziging kan in beginsel worden genomen met een gewone meerderheid van stemmen. ${ }^{42}$ Een dergelijke regeling is binnen de grenzen van Boek $2 \mathrm{BW}$ toegestaan. ${ }^{43} \mathrm{In}$ de noteringseisen van Euronext Amsterdam worden op dit punt - anders dan in de VS - evenmin aanvullende voorwaarden opgelegd. ${ }^{44}$

Hoewel het onderscheid tussen midstream- en initiële invoering naar Nederlands recht niet wordt gemaakt, is het onderscheid niettemin relevant voor de positie van minderheidsaandeelhouders. Zou de (initiële) invoering plaatsvinden in het kader van een grensoverschrijdende statutaire zetelverplaatsing, dan bestaat voor de zittende minderheidsaandeelhouders in principe een uittreedrecht. ${ }^{45}$ Bovendien zou, indien de regeling voorafgaand aan een beursgang wordt ingevoerd, kunnen worden beargumenteerd dat nieuwe aandeelhouders op grond van het prospectus kunnen weten waarin ze gaan beleggen, anders gesteld: dat de aandeelhouders het mogelijke effect van - door een bijzondere stemrechtregeling versterkte positie van - een controlerende aandeelhouder op de vennootschap kunnen laten meewegen in de prijs die zij bereid zijn te betalen voor de aandelen. ${ }^{46}$

39. Zie voor een beschrijving van het belang van dit onderscheid bij het loyaliteitsstemrecht naar Frans recht bijv. reeds G.J. Boelens, Oligarchische clausules naar buitenlands recht (diss. Amsterdam VU), Kampen: J.H. Kok N.V. 1946, p. 41.

40. Zie voor dual-class-aandelen ook Buirma 2016

41. Zie ook Kamerstukken II 2010/11, 31980, 48, p. 3. Anders: Van der Heijden/Van der Grinten/Dortmond, Handboek voor de naamloze en de besloten vennootschap, Deventer: Kluwer 2013, p. 320, waar wordt verdedigd dat loyaliteitsdividend, zolang dat niet in de wet is geregeld, slechts ingevoerd kan worden met instemming van alle aandeelhouders die bij het loyaliteitsdividend worden betrokken. Zie in die zin ook reeds P.J. Dortmond, Zittenblijvers bevoordeeld, Ondernemingsrecht 2006/180.

42. Zie art. 2:120 BW.

43. Zie art. 2:105 BW (voor loyaliteitsdividend) en art. 2:118 BW (voor meervoudig stemrecht) en het beginsel van gelijke behandeling van aandeelhouders neergelegd in art. 2:92 lid 2 BW.

44. Zie <www.euronext.com $/ \mathrm{nl} /$ regulation/regulated-markets $>$.

45. Zie naar Nederlands recht bijv. art. 2:333h BW. Vgl. over het uittreedrecht ook De Brauw 2016 en M. van Olffen, Grensoverschrijdende herstructurering van ondernemingen, in: G. van Solinge e.a., Herstructurering van ondernemingen in financiële moeilijkheden (Serie vanwege het Van der Heijden Instituut, deel 124), Deventer: Kluwer 2014, p. 65. Zie specifiek over het 'cash exit right' naar Italiaans recht bij de FCA-transactie Bootsma 2015.

46. Zie bijv. S.M. Bainbridge, What to do about dual-class stock (if anything)?, 5 november 2015 en Shareholder rights activists rethinking one share one vote: Implementing time-phased voting, 24 juni 2016, te raadplegen via <www.professorbainbridge.com>: 'Dual class IPOs are the clearest case. Public investors who don't want lesser voting rights stock simply won't buy it. Those who are willing to purchase it presumably will be compensated by a lower per share price than full voting rights stock would command (...).' Dat standpunt klinkt door in Kamerstukken II 2010/11, 31980, 48, p. 3 en 6.
Bij midstream-invoering is de positie van minderheidsaandeelhouders anders. De (minderheids)aandeelhouders in DSM die het niet eens waren met de voorgestelde statutenwijziging hadden weinig andere mogelijkheden dan een gang naar de Ondernemingskamer. Bij DSM golden voor de tussentijdse invoering van loyaliteitsdividend, zoals is opgemerkt, de gewone regels voor een statutenwijziging (geen versterkte meerderheid of - laat staan - instemming van alle aandeelhouders) en bestond bovendien geen uittreedrecht voor zittende aandeelhouders die het niet met de invoering van het loyaliteitsdividend eens waren.

In verband met het ontbreken van een uittreedrecht is in het verleden wel opgemerkt dat de exit-mogelijkheden voor minderheidsaandeelhouders in het Nederlandse vennootschapsrecht beperkt zijn. ${ }^{47}$ Dat was overigens nog voor de invoering van het verplicht bod in de zin van artikel 5:70 van de Wet op het financieel toezicht (Wft). ${ }^{48}$ De geschillenregeling is bijvoorbeeld niet van toepassing op beurs-NV's. ${ }^{49}$ In de literatuur is gepleit voor een ruimer toepassingsbereik van de geschillenregeling. ${ }^{50}$ Die gedachte is overigens mede in het licht van de invoering van het verplicht bod weer verlaten door Bulten. ${ }^{51}$

Het is de vraag of die redenering vandaag de dag nog steeds opgaat. Zoals in paragraaf 2.4 is opgemerkt, zijn de vennootschappen met bijzondere stemrechtaandelen vrijwel zonder uitzondering op de NYSE of NASDAQ genoteerd. De verplicht-bodregeling geldt niet buiten de EU/EER.52 De Nederlandse wetgever zal dan een keuze moeten maken of hij minderheidsaandeelhouders in dergelijke beurs-NV's in den vreemde $^{53}$ met multiple corporate citizenship ${ }^{54}$ die bijzondere stemrechtaandelen willen invoeren een exit-mogelijkheid wil bieden via het Nederlandse vennootschapsrecht (in Boek 2 $\mathrm{BW}$ aanknopend bij de statutaire zetel), of vertrouwt op min-

47. Zie bijv. L. Timmerman \& A. Doorman, Rights of minority shareholders in the Netherlands, Electronic Journal of Comparative Law (64) 2002, beschikbaar via <www.ejcl.org>.

48. Art. 5:70 Wft vormt ook een belangrijke waarborg voor de bescherming van de belangen van minderheidsaandeelhouders. In die zin bijv. ook Eumedion 2015, p. 7 (en Eumedion 2016, p. 7 ).

49. Zie art. 2:335 lid 2 BW.

50. Zie bijv. C.D.J. Bulten, Pleidooi voor een ruimer toepassingsbereik van de geschillenregeling, in: G. van Solinge \& M. Holtzer (red.), Geschriften vanwege de Vereniging Corporate Litigation 2003-2004 (Serie vanwege het Van der Heijden Instituut, deel 75), Deventer: Kluwer 2004, p. 128 en H.J. de Kluiver, De flexibele kapitaalvennootschap. Van de Flex- naar de Beurs-BV, in: J.M.M. Maeijer e.a., Flexibele rechtsvormen (Serie vanwege het Van der Heijden Instituut, deel 98), Deventer: Kluwer 2008, p. 20: 'Voorts kan art. 335 (geschillenregeling) lid 2 worden geschrapt. Daarmee wordt de (...) geschillenregeling van toepassing op alle kapitaalvennootschappen. Dat kan een welkome aanvulling zijn op het enquêterecht, ook, en juist, waar het betreft beursgenoteerde vennootschappen.'

51. Zie C.D.J. Bulten, De geschillenregeling ten gronde (diss. Nijmegen; Serie vanwege het Van der Heijden Instituut, deel 108), Deventer: Kluwer 2011, p. 36.

52. Zie ook De Brauw 2016.

53. Zie Bootsma \& Hijink 2014.

54. Zie Bootsma, Hijink \& In 't Veld 2015. 


\section{Maandblad}

Ondernemingsrecht

derheidsbescherming in 'vreemd' financieel recht (aanknopend bij de plaats van de beursnotering).

De verplicht-bodregeling is bovendien niet van toepassing als de controlerende aandeelhouder de bijzondere stemrechtaandelen (met in totaal meer dan 30\% van de stemrechten) verkrijgt voordat de aandelen in de nieuwe beurs-NV worden toegelaten tot de handel op een gereglementeerde markt. ${ }^{55}$ In dat geval kan eveneens worden beargumenteerd dat een nieuw toetredende aandeelhouder bekend zal zijn met het bestaan van een controlerende aandeelhouder met bijzondere stemrechtaandelen en zich in die zin door de aankoop van aandelen vrijwillig onderwerpt aan de statutaire regeling.

\section{Bijzondere stemrechtaandelen in het licht van het Eumedion-position paper}

Eumedion heeft vorig jaar in haar concept-position paper over de positie van minderheidsaandeelhouders in vennootschappen met een controlerende aandeelhouder gepleit voor een wettelijke regeling voor bijzondere stemrechtaandelen. ${ }^{56}$ Eumedion is kritisch over bijzondere stemrechtaandelen, omdat vooral controlerende aandeelhouders van deze - in de terminologie van Eumedion - 'kunstgrepen' profiteren. ${ }^{57}$ Eumedion stelt de volgende wettelijke begrenzing op het gebruik van bijzondere stemrechtaandelen voor:

'Het aantal extra stemrechten voor één aandeelhouder uit hoofde van high voting stock bij dual-class aandelen of van loyaliteitsaandelen zou niet meer mogen bedragen dan 5\% van alle stemrechten. 58

\subsection{Regeling in de wet of Corporate Governance Code}

Eumedion opteert in de concept-position paper voor een wettelijke regeling voor bijzondere stemrechtaandelen. Eumedion stelt dat de Corporate Governance Code (hierna: Code) een te 'licht' instrument is voor vennootschappen met een controlerende aandeelhouder die ook gelieerd is aan het bestuur en/of de raad van commissarissen. ${ }^{59}$ Toegespitst op bijzondere stemrechtaandelen (en loyaliteitsdividend) ben ik het met Eumedion eens dat de Code niet het meest geschikte instrument is voor het opnemen van aanvullende waarborgen voor de bescherming van de positie van minderheidsaandeelhouders. De Code zou het gebruik van deze instrumenten wel

55. Zie Van Olffen 2013 en P. Cronheim, Loyal lawyers and loyalty shares, in: J.C. Cascante, A. Spahlinger \& S. Wilske (red.), Global wisdom on business transactions, international law and dispute resolution (Festschrift voor Gerhard Wegen), München: Verlag C.H. Beck 2015, p. 202.

56. Eumedion 2015. Zie voor een eerste reactie van de minister van Veilig heid en Justitie op de conceptvoorstellen Kamerstukken II 2015/16, Aanhangsel, 667. Zie over de definitieve versie van de position paper (Eumedion 2016) het naschrift bij deze bijdrage.

57. Eumedion 2015, p. 4 (en Eumedion 2016, p. 5 ).

58. Eumedion 2015, p. 12, onder verwijzing naar J.M. de Jongh, Privatisering, bescherming en algemeen belang. De voorgenomen beursgang van ABN AMRO, WPNR 2015/7048 en Bootsma 2015.

59. Zie Eumedion 2015, p. 13 (en Eumedion 2016, p. 11). Zie over de 'inherente zwakte van het "pas toe of leg uit"-beginsel' in deze context ook reeds de brief van 22 oktober 2013 van de leden van de voormalige commissie-Tabaksblat uit 2003 aan de minister van Economische Zaken, te raadplegen via <www.eumedion.nl $>$. kunnen faciliteren, maar niet, althans minder goed dan in een wettelijke regeling, kunnen reguleren. ${ }^{60}$

In de inleiding merkte ik op dat de Monitoring Commissie het onderwerp reeds tien jaar volgt. De Monitoring Commissie concludeerde in 2007 naar aanleiding van de DSM-casus dat zij positief staat tegenover initiatieven van vennootschappen om langetermijnaandeelhouderschap te bevorderen, maar dat zij het gebruik daarvan wil overlaten aan de markt. ${ }^{61}$ De Monitoring Commissie acht het daarbij van belang dat de instrumenten in het buitenland herkenbaar zijn en in brede kring worden begrepen. ${ }^{62}$ Recentelijk heeft de Monitoring Commissie in het kader van een onderzoek naar de internationale context van de Code ook het loyaliteitsdividend onderzocht. ${ }^{63}$ Uit het in opdracht van de Monitoring Commissie verrichte onderzoek ${ }^{64}$ komt naar voren dat het loyaliteitsdividend in geen enkele onderzochte buitenlandse corporate governance code aan de orde komt. In landen waar een regeling voor loyaliteitsdividend bestaat, zoals in Frankrijk en Italië, is die eveneens in de wet, en niet in een corporate governance code, opgenomen. ${ }^{65}$ Voor loyaliteitsstemrecht bestaat in die landen eveneens een wettelijke regeling. ${ }^{66}$

Een belangrijke reden waarom een regeling in de Nederlandse Code op dit punt minder effectief zou zijn, is bovendien dat de bijzondere stemrechtaandelen vrijwel zonder uitzondering worden toegepast door beurs-NV's in den vreemde. ${ }^{67}$ Deze vennootschappen met (uitsluitend) een beursnotering buiten Nederland blijven weliswaar in het voorstel voor herziening

60. Zie over het regulerende aspect hierna in par. 4.2.

61. Monitoring Commissie Corporate Governance Code, Advies over de verhouding tussen vennootschap en aandeelhouders en over het toepassingsbereik van de Code, mei 2007, p. 14-15. Over het Advies C.W. de Monchy in Ondernemingsrecht 2007/120.

62. Zie Monitoring Commissie Corporate Governance Code, Consultatiedocument, december 2006, p. 23: 'In een klein land met een open economie hebben Nederlandse ondernemingen geen werkelijke mogelijkheid te kiezen voor maatregelen waarmee zij zich internationaal isoleren.' Over het Consultatiedocument R.H. Maatman, M. Meinema \& A.F. Verdam in Ondernemingsrecht 2007/31.

63. Monitoring Commissie Corporate Governance Code, Rapport monitoring boekjaar 2014, februari 2016, p. 49-50, waarover A.A. Bootsma in Ondernemingsrecht 2016/36.

64. R.B.H. Hooghiemstra, W. Kaufmann, K. van Veen \& C.L.M. Hermes, Onderzoek naar de internationale context van de Nederlandse Corporate Governance Code, Rijksuniversiteit Groningen 2015, te raadplegen via <www.mccg.nl>.

65. Zie voor loyaliteitsdividend naar Frans recht art. L232-14 Code de commerce en voor loyaliteitsdividend naar Italiaans recht art. 127-quater Testo Unico della Finanza. Zie Bootsma 2015 voor verdere verwijzingen.

66. Zie voor loyaliteitsstemrecht naar Frans recht art. L225-123 en L225-124 Code de commerce en voor loyaliteitsstemrecht naar Italiaans recht art. 127-quinquies Testo Unico della Finanza. Zie Bootsma 2015 voor verdere verwijzingen.

67. Zie par. 2.4. 
van de Code onder de reikwijdte van de Code vallen, ${ }^{68}$ maar naar mijn indruk blijft voor beurs-NV's in den vreemde de mogelijkheid bestaan om de Code na te leven door toepassing van een buitenlandse corporate governance code. ${ }^{69}$ Eventuele waarborgen opgenomen in de Nederlandse Code kunnen derhalve bij beurs-NV's in den vreemde relatief eenvoudig, met een generieke explain dat een buitenlandse code wordt toegepast, buiten beschouwing worden gelaten.

\subsection{Begrenzing van het gebruik van bijzondere stemrechtaandelen}

Het voorstel van Eumedion valt goed te begrijpen als wordt aangenomen dat bijzondere stemrechtaandelen uitsluitend dienen ter bevordering van langetermijnaandeelhouderschap bij beursvennootschappen met een relatief verspreid aandelenbezit, zoals bij DSM het geval was. ${ }^{70}$ In de praktijk blijken de bijzondere stemrechtaandelen met name te worden gebruikt door controlerende aandeelhouders.

In het licht van het in de vorige paragrafen behandelde onderscheid tussen midstream- en IPO-invoering van bijzondere stemrechtaandelen kan de vraag worden gesteld of een dergelijke, per definitie arbitraire en rigide, wettelijke begrenzing wel in alle gevallen wenselijk en noodzakelijk is. ${ }^{71}$ Geconcludeerd is dat minderheidsaandeelhouders uitsluitend bij midstream-invoering van bijzondere stemrechtaandelen, door middel van een statutenwijziging met een volstrekte meerderheid van stemmen, 'bekneld' kunnen raken bij een vennootschap met een controlerende aandeelhouder. Een wettelijke begrenzing op het gebruik van bijzondere stemrechtaandelen zou om die reden alleen hoeven te gelden voor midstreaminvoering, waarmee de flexibiliteit die het huidige Nederlandse vennootschapsrecht op dit punt biedt bij een invoering voorafgaand aan een beursgang behouden kan blijven. ${ }^{72}$

Bij midstream-invoering is het overigens eveneens de vraag of een beperking van bijzondere stemrechtaandelen tot $5 \%$ van alle stemrechten per aandeelhouder in dogmatische en praktische zin de meest wenselijke wettelijke begrenzing vormt. Fei-

68. Zie Monitoring Commissie Corporate Governance Code, De Nederlandse Corporate Governance Code. Voorstel voor herziening. Een uitnodiging tot commentaar, februari 2016, beschikbaar via <www.mccg. $\mathrm{nl}>$, p. 54 . Zie voor een mooie beschouwing over een onderdeel van het consultatievoorstel in dit tijdschrift F.G.K. Overkleeft \& J.H.L. Beckers, Het consultatievoorstel voor een herziene Code en langetermijnwaardecreatie: alleen 'jam tomorrow' of ook 'jam today'?, MvO 2016, afl. 3-4, p. 43-46. Zie voorts o.a. de bijdragen aan het themanummer corporate governance onder gastredacteurschap van Ch.E. Honée, Ondernemingsrecht 2016, afl. 9 en H. Koster, De herziening van de Nederlandse Corporate Governance Code: enkele observaties, WPNR 2016/7112.

69. Zie Handelingen I 2003/04, 28179, 38 en Kamerstukken II 2006/07, 31083, 1, p. 8. Zie over die mogelijkheid nader A.A. Bootsma \& J.B.S. Hijink, De beurs-NV in den vreemde. Toepassing en naleving van de Nederlandse Corporate Governance Code, MAB 2014-5, p. 198-209.

70. Zie in die zin reeds De Jongh 2009. Zie ook par. 2.3.

71. Vgl. in die zin G.N.H. Kemperink, Vennootschappelijk toezicht op de doelvennootschap bij openbare biedingen (diss. Rotterdam; Uitgave vanwege het Instituut voor Ondernemingsrecht, deel 92), Deventer: Kluwer 2013, p. 71-74.

72. Zie ook De Brauw 2016 telijk wordt daarmee een grens gesteld aan de mate waarin met bijzondere stemrechtaandelen kan worden afgeweken van het proportionaliteitsbeginsel (one share, one vote). Dat verdraagt zich niet goed met andere toegelaten afwijkingen van het one share, one vote-beginsel, zoals certificering van aandelen. ${ }^{73}$ Bovendien zou een controlerende aandeelhouder(sfamilie) een dergelijke beperking in de praktijk gemakkelijk kunnen omzeilen door het totale stemrechtbelang in de (familie)vennootschap op te splitsen in meerdere 5\%-pakketten.

Indien de wetgever bij het gebruik van bijzondere stemrechtaandelen toch wettelijke grenzen aan afwijking van het proportionaliteitsbeginsel wenst te stellen, zou bij loyaliteitsstemrecht gekozen kunnen worden voor maximaal een verdubbeling van het stemrecht ${ }^{74}$ en voor dual-class-aandelen een maximale verhouding tussen low voting en high voting stock van bijvoorbeeld $1: 10 .^{75}$ In plaats van een wettelijke begrenzing kan bij midstream-invoering van bijzondere stemrechtaandelen bovendien worden gedacht aan een bijzonder uittreedrecht voor zittende minderheidsaandeelhouders die buiten hun wil beklemd zijn geraakt en daarmee geen rekening behoefden te houden bij de verkrijging van de aandelen. ${ }^{76}$ Voorts kan gedacht worden aan een 'sunset'-bepaling, een regeling waarbij op het moment van de invoering van de bijzondere stemrechtaandelen reeds wordt overeengekomen dat het bijzondere stemrecht na verloop van een bepaalde termijn vervalt. ${ }^{77}$ Een ander alternatief is het vereisen van een versterkte meerderheid van bijvoorbeeld twee derde van de stemmen of een

73. Zie over certificering van aandelen als alternatief voor loyaliteitsaandelen bijv. Z. Tali \& F.J. de Graaf, Loyaliteitsdividend, registratiedividend en institutionele beleggers: vaste relatie of betaalde liefde?, Ondernemingsrecht 2007/45.

74. Zie art. L225-123 en L225-124 Code de commerce, waarover De Jongh 2009 en Kamerstukken II 2010/11, 31980, 48, p. 6. Vgl. voor loyaliteitsdividend art. L232-14 Code de commerce, waarover o.a. Kamerstukken II $2010 / 11,31980,48$, p. 5 .

75. Een dergelijke begrenzing geldt bijv. voor dual-class-aandelen in Zweden. Zie ook Eumedion 2015, p. 16.

76. Vgl. Bootsma 2015 over het 'cash exit right' van art. 2437 van het Italianse Burgerlijk Wetboek dat wel geldt bij een besluit tot grensoverschrijdende statutaire zetelverplaatsing, maar niet bij een besluit tot invoering van loyaliteitsstemrecht. Zie ook Kamerstukken II 2010/11, 31980, 48, p. 6.

77. Zie bijv. A.M. Pacces, Exit voice and loyalty from the perspective of shareholder activism, Erasmus Law Review 2016 (te verschijnen): 'A major disadvantage of dual-class shares and entrenched control structures in general is that they are difficult to remove once they are established. This may lead to inefficiency because the same company that once benefited from entrenched control may suffer from it later on. The need for controllers to offer investors a sunset arrangement to enable a dual-class recapitalization overcomes this problem.' Zie voorts Berger, Davidoff \& Benjamin 2016, p. 39. Zie ook reeds P.M.H. Snel, Het Vraagstuk van de Meerstemmige Aandeelen in Frankrijk, NV 1930, p. 72: 'Tegenstanders van [meervoudig stemrecht] spreken in dat verband van financieele feodaliteit of oligarchie, vooral als daar nog bij komt, dat die aandeelen door erfopvolging aan familieleden overgaan. De beperking van den geldigheidsduur van het preferentierecht kan hiervoor eene oplossing brengen.' 
majority of minority-stemvereiste voor een besluit tot statutenwijziging ter zake van bijzondere stemrechtaandelen. ${ }^{78}$

Elk van deze alternatieven kent voor- en nadelen. Daar ga ik op deze plaats niet verder op in. Waar het mij hier om gaat, is te benadrukken dat er bij het gebruik van bijzondere stemrechtaandelen geen one size fits all bestaat. ${ }^{79}$ Het is daarom van belang dat een wettelijke regeling voor loyaliteitsdividend en bijzondere stemrechtaandelen voldoende flexibiliteit behoudt. Dat kan in de eerste plaats door een onderscheid te maken tussen initiële en tussentijdse (midstream) invoering, waarbij naar mijn mening met name in het laatste geval reden zou kunnen bestaan voor aanvullende bescherming van de positie van minderheidsaandeelhouders. De door Eumedion in de conceptposition paper voorgestelde wettelijke begrenzing is één manier waarop beknelling van minderheidsaandeelhouders als gevolg van het gebruik van bijzondere stemrechtaandelen door een controlerende aandeelhouder zou kunnen worden voorkomen en dient te worden afgewogen tegen alternatieve wettelijke begrenzingen, waarvan ik er enkele heb genoemd. ${ }^{80}$

\section{Conclusie}

Vanuit de hoek van institutionele beleggers wordt de trend in het gebruik van bijzondere stemrechtaandelen - loyaliteitsstemrecht, dual-class-aandelen en andere vormen van meervoudig stemrecht - bij een aantal beurs-NV's met argusogen gevolgd. Eumedion heeft recentelijk in een position paper voorstellen gedaan om het gebruik van bijzondere stemrechtaandelen te reguleren. In dat verband is het interessant te constateren dat bijzondere stemrechtaandelen vooralsnog geen aanleiding hebben gegeven tot juridische procedures van minderheidsaandeelhouders, terwijl het loyaliteitsdividendplan van

78. Een twee derde meerderheid van de stemmen geldt voor statutenwijziging in Frankrijk. In Italië geldt na een aanloopperiode waarbij loyaliteitsstemrecht met een gewone meerderheid van stemmen ingevoerd kon worden (zie Bootsma 2015) inmiddels ook een versterkte, twee derde meerderheid.

Zie voor een rechtseconomisch pleidooi voor een majority of minoritystemvereiste Pacces 2016: 'As revealed by the recent European experience, loyalty shares operate as dual-class shares in disguise. This outcome could be improved by allowing dual class recapitalizations explicitly, but subject to a majority of minority vote. This "sticky default" solution would screen for the companies for which limiting the influence of activists is efficient and induce these companies to negotiate time-bound restrictions with institutional investors.'

79. In die zin ook De Brauw 2016.

80. Zie reeds Snel 1930, p. 74: 'In het algemeen kan men zeggen, dat de goede en slechte resultaten afhangen van den aard der onderneming, van de doseering en van de eerlijkheid die bij het gebruik van de (...) aandelen [met meervoudig stemrecht] betracht wordt.' Vgl. voorts E.L. Kayenbergh, Aandeelen met meervoudig stemrecht, NV 1933, p. 67: 'Maar aldra bleken die aandelen [met meervoudig stemrecht] de goede en slechte eigenschappen te bezitten van Aesopus' tongen: zeer nuttig en tevens zeer schadelijk. Zij beschermden de levende krachten van de vennootschap tegen het anonieme kapitaal, maar leidden ook tot misbruiken.' en M.J. Denijs, Het stemrecht in de naamlooze vennootschap naar Nederlandsch recht, Amsterdam: H.J. Paris 1936, p. 66: 'Meervoudig stemrecht kan ongetwijfeld, bij goed hanteeren zijn voordeelen afwerpen en ik acht het bestrijden der misbruiken doelmatiger dan het afschaffen van iets wat nuttig kan zijn.'
DSM indertijd wel door minderheidsaandeelhouders aan de rechter is voorgelegd.

Naast enkele andere verschillen is als een belangrijk verschil tussen de DSM-casus en de beurs-NV's met bijzondere stemrechtaandelen gesignaleerd dat DSM het loyaliteitsdividend midstream - door middel van een statutenwijziging bij een bestaande beurs-NV met zittende aandeelhouders - wilde invoeren, terwijl de bijzondere stemrechtaandelen zijn ingevoerd door nieuwe beurs-NV's, voorafgaand aan een beursgang of in het kader van een grensoverschrijdende statutaire zetelverplaatsing waarbij een nieuwe holdingvennootschap wordt opgericht. Op basis van een korte rechtsvergelijking met de VS is beargumenteerd dat het onderscheid tussen midstream- en IPO-invoering van loyaliteitsdividend of bijzondere stemrechtaandelen relevant kan zijn voor de positie van minderheidsaandeelhouders. Indien wordt aangenomen dat minderheidsaandeelhouders uitsluitend bij midstream-invoering bekneld kunnen raken, zou bij invoering voorafgaand aan een beursgang, waar aandeelhouders via het prospectus geïnformeerd zijn over de ingevoerde bijzondere stemrechtaandelen, of in het kader van een grensoverschrijdende statutaire zetelverplaatsing, waar zittende aandeelhouders die niet instemmen in beginsel een uittreedrecht hebben, flexibiliteit in het gebruik van bijzondere stemrechtaandelen behouden kunnen blijven.

In de woorden van de minister van Veiligheid en Justitie:

'Het is niet eenvoudig te bepalen of beklemming [van minderheidsaandeelhouders] zich in de praktijk snel zal voordoen en zo ja, welke grens dan gepast is. De eventuele grens moet voldoen aan de eisen van proportionaliteit en moet ook in de praktijk hanteerbaar zijn. Teneinde een gefundeerde keuze te maken lijkt een meer economische analyse van de aantrekkelijkheid van loyaliteitsdividend en de kans op beklemming noodzakelijk.' ${ }^{81}$

Ik hoop daartoe in deze bijdrage, met het benadrukken van het belang voor minderheidsbescherming van het onderscheid tussen midstream- en IPO-invoering van loyaliteitsdividend en bijzondere stemrechtaandelen, een aanzet te hebben gegeven. De reactie van de Nederlandse wetgever op de Eumedionvoorstellen wordt met veel belangstelling afgewacht.

\section{Naschrift}

Op 28 juni 2016 is de position paper van Eumedion over de positie van minderheidsaandeelhouders in vennootschappen met een controlerende aandeelhouder definitief vastgesteld. ${ }^{82}$ In lijn met deze bijdrage makt Eumedion in de definitieve voorstellen een onderscheid tussen midstream- en IPO-invoering van bijzondere stemrechtaandelen. $\mathrm{Bij}$ een voorstel tot statutenwijziging dat erin voorziet om aan de controlerende aandeelhouder in een beurs-NV bijzondere stemrechtaandelen

81. Kamerstukken II 2010/11, 31980, 48, p. 5.

82. Eumedion 2016. 
toe te kennen, stelt Eumedion voor dat de controlerende aandeelhouder (en partijen die aan hem gelieerd zijn) niet zou(den) mogen deelnemen aan de besluitvorming in de algemene vergadering over die voorgestelde statutenwijziging. ${ }^{83}$ Anders gesteld zou een meerderheid van de 'onafhankelijke' aandeelhouders, akkoord moeten gaan met de statutenwijziging. Een dergelijk majority of minority-stemvereiste is in lijn met voorstellen in de literatuur. ${ }^{84}$ Ik merk daarbij op dat het Nederlandse vennootschapsrecht met een majority of minority-stemvereiste voor de midstream-invoering van bijzondere stemrechtaandelen strenger zou worden dan Frankrijk, Italië en de VS. ${ }^{85}$

Eumedion ziet echter ook dat de effectiviteit van dit voorstel gering is, omdat de bijzondere stemrechtaandelen in de praktijk veelal worden toegekend voorafgaand aan een beursgang of in het kader van een (grensoverschrijdende) statutaire zetelverplaatsing. ${ }^{86}$ Voor IPO-invoering komt Eumedion om die reden met drie aanvullende voorstellen: (1) het voorstel tot wijziging van de statuten ter zake van de invoering van bijzondere stemrechtaandelen dient tijdens de algemene vergadering als separaat punt in stemming te worden gebracht; (2) de bijzondere aandelenstructuur moet jaarlijks door de raad van commissarissen (hierna: $\mathrm{RvC}$ ) geëvalueerd worden, waarbij de uitkomsten van die evaluatie in het $\mathrm{RvC}$-verslag worden verantwoord; en (3) de statuten dienen een horizonbepaling te bevatten, die erin voorziet dat de regeling van bijzondere stemrechtaandelen na verloop van een bepaalde termijn automatisch vervalt. ${ }^{87}$

Het eerste voorstel is ontleend aan de interpretatie van de SEC van 27 oktober 2015 inzake Exchange Act Rule 14a-4(a) (3). ${ }^{88}$ Op grond van die interpretatie moet iedere in verband met een voorgenomen overnametransactie door te voeren verandering in de corporate governance van de vennootschap als separaat punt op de algemene vergadering in stemming worden gebracht. ${ }^{89}$ Het effect van dit voorstel zal relatief beperkt zijn. Het voorstel kan weliswaar een bijdrage leveren aan de transparantie over de besluitvorming, maar de goedkeuring van corporate governance wijzigingen, waaronder de invoering van bijzondere stemrechtaandelen, kan door de vennootschap

83. Eumedion 2016, p. 10.

84. Zie bijv. het voorstel van Pacces 2016, aangehaald in noot 77 .

85. In zowel het Franse als het Italiaanse vennootschapsrecht geldt een twee derde meerderheid van de stemmen, waarbij de controlerende aandeelhouder mag meestemmen (zie noot 77). In het vennootschapsrecht van de VS bestaat evenmin een majority of minority-stemvereiste voor de invoering van bijzondere stemrechtaandelen. In de noteringsvoorwaarden van de NYSE en NASDAQ worden wel beperkingen opgelegd aan de midstream-invoering van bijzondere stemrechtaandelen (zie par. 3.1).

86. Eumedion 2016, p. 11. Zie nader par. 2.5 van deze bijdrage.

87. Eumedion 2016, p. 11.

88. Zie Eumedion 2016 (feedback statement), p. 7.

89. Zie <www.sec.gov/divisions/corpfin/guidance/exchange-act-rule-14a $-4 a 3 . h t m>$ (geraadpleegd op 1 juli 2016), waarover ook Bootsma, Hijink \& In 't Veld 2015 als voorwaarde gesteld worden voor het doorgaan van de (grensoverschrijdende) statutaire zetelverplaatsing. ${ }^{90}$

Het voorstel van Eumedion genoemd onder (2) om de bijzondere stemrechtaandelen jaarlijks door de $\mathrm{RvC}$ te laten evalueren en over die evaluatie verantwoording af te laten leggen in het RvC-verslag kan eraan bijdragen dat het effect van de bijzondere stemrechtaandelen blijvend onderwerp van de dialoog met de aandeelhouders van de desbetreffende vennootschap zal zijn. De $\mathrm{RvC}$ zal dan in de evaluatie, ook indien de controlerende aandeelhouder in de $\mathrm{RvC}$ is vertegenwoordigd, ${ }^{91}$ moeten beoordelen of de bijzondere stemrechtaandelen (nog steeds) in het belang van de vennootschap en de daarmee verbonden onderneming zijn. ${ }^{92}$

De voorgestelde horizonbepaling is vanuit theoretisch oogpunt interessant. ${ }^{93}$ De gedachte is dat bijzondere stemrechtaandelen die op het moment van invoering efficiënt kunnen zijn dat na verloop van een bepaalde termijn, als de omstandigheden bij de desbetreffende vennootschap zijn veranderd, niet meer noodzakelijkerwijs hoeven te zijn. ${ }^{94}$ In de praktijk komen dergelijke sunset-bepalingen echter nog betrekkelijk weinig voor in de statuten van beursvennootschappen. Bebchuk geeft daarvoor als reden dat de aandeelhouders ten tijde van de beursgang niet geïnteresseerd zijn in de governance van de vennootschap in de (verre) toekomst. ${ }^{95}$

Over de termijn na afloop waarvan bijzondere stemrechtaandelen op grond van de statuten automatisch zouden vervallen kan gediscussieerd worden. Omdat geen sprake is van one size fits all ${ }^{96}$ zal de lengte van de termijn overgelaten kunnen worden aan de statuten van de desbetreffende vennootschap. Eumedion noemt een termijn van drie tot vijf jaar, maar langere termijnen of andere voorwaarden zijn, afhankelijk van de omstandigheden bij de desbetreffende vennootschap, eveneens denkbaar. ${ }^{97}$

90. Vgl. D.W. Bernstein, E. Santucci \& J. Haggerty, SEC Guidance on Voting During M\&A Transactions, 29 november 2015, beschikbaar via <https://corpgov.law.harvard.edu/>: 'It is unlikely that there will be many instances in which shareholders will vote in favor of a merger but vote against governance changes that are a condition to the merger's taking place. Therefore, the principal effect of the new SEC guidance is likely to be to focus attention on governance changes, and possibly to offer plaintiffs' attorneys an opportunity to challenge governance changes rather than (or in addition to) challenging the adequacy of merger consideration.'

91. Vgl. Eumedion 2016, p. 5-6.

92. Vgl. art. 2:140 lid 2 BW.

93. Zie de bronnen aangehaald in noot 76 .

94. Zie ook L.A. Bebchuk, Why firms adopt antitakeover arrangements, University of Pennsylvania Law Review (152) 2003, p. $751-752$ en L. Enriques, R.J. Gilson \& A.M. Pacces, The case for an unbiased takeover law (with an application to the European Union), Harvard Business Law Review (4) 2014, p. 126.

95. Bebchuk 2003, p. 752 noemt als verklaring daarvoor een 'bounded attention problem' van aandeelhouders.

96. Vgl. par. 4.2 onder verwijzing naar De Brauw 2016.

97. Zie bijv. Bebchuk 2003, p. 752: 'say, twenty-five years, the death of certain founders, or the reaching of a certain ownership structure.' 
Eumedion meent dat de voorstellen genoemd onder (1), (2) en (3) zich lenen voor opname als best practice-bepalingen in de Code. ${ }^{98}$ Daarbij maak ik de kanttekening dat opname van deze bepalingen in de Code voor beurs-NV's in den vreemde met bijzondere stemrechtaandelen minder effectief zal zijn, vanwege de mogelijkheid om door middel van een generieke explain in plaats van de (Nederlandse) Code een buitenlandse corporate governance code toe te passen. ${ }^{99}$

Hoewel de Eumedion-position paper een reflectie blijft van de opvattingen van Eumedion-deelnemers (institutionele beleggers), ${ }^{100}$ wordt in de position paper bij het gebruik van bijzondere stemrechtaandelen gezocht naar een balans tussen faciliteren en reguleren. Van de zijde van (adviseurs van) beursvennootschappen wordt gepleit voor behoud van flexibiliteit in het gebruik van bijzondere stemrechtaandelen, terwijl van de zijde van (vertegenwoordigers van) beleggers wordt gepleit voor het opleggen van beperkingen, zoals uitsluiting van opname van de aandelen in vennootschappen met bijzondere stemrechtaandelen in een beleggingsindex of zelfs een totaalverbod op het gebruik van bijzondere stemrechtaandelen. ${ }^{101}$ Het voorstel in de concept-position paper om het gebruik van bijzondere stemrechtaandelen per aandeelhouder te beperken tot $5 \%$ van alle stemrechten zou mijns inziens te ver in de beperkende richting doorslaan. ${ }^{102}$ De definitieve voorstellen bieden naar mijn mening een beter evenwicht tussen faciliteren en reguleren. Midstream-invoering is in de definitieve position paper nog slechts mogelijk onder de, weliswaar internationaal gezien zware, eis van een majority of minority-instemming. Daar staat echter tegenover dat bij IPO-invoering flexibiliteit wordt behouden. Bij opname in de Code van de drie voorstellen bij IPO-invoering heb ik enige bedenkingen, in het bijzonder over de effectiviteit van regeling in de Code bij beurs-NV's in den vreemde. Omdat die voorstellen zien op IPO-invoering van bijzondere stemrechtaandelen zou echter beargumenteerd kunnen worden dat een 'lichte' regeling in de Code hier volstaat, omdat de positie van minderheidsaandeelhouders bij IPO-invoering van bijzondere stemrechtaandelen, anders dan bij midstream-invoering, minder snel in het gedrang komt.

98. Eumedion 2016, p. 11.

99. Zie par. 4.1 van deze bijdrage.

100. Zie Eumedion 2016 (feedback statement), p. 2.

101. Zie Eumedion 2016 (feedback statement), p. 6-7.

102. Zie par. 4.2 van deze bijdrage. 